Research Report No. 11/2008

\title{
Anxieties and Aspirations: A Schematic Note on the Toronto Group for the Study of International, Transnational and Comparative Law
}

Michael Fakhri

Follow this and additional works at: http:/ / digitalcommons.osgoode.yorku.ca/clpe

\section{Recommended Citation}

Fakhri, Michael, "Anxieties and Aspirations: A Schematic Note on the Toronto Group for the Study of International, Transnational and Comparative Law" (2008). Comparative Research in Law \& Political Economy. Research Paper No. 11/2008.

http://digitalcommons.osgoode.yorku.ca/clpe/185 


\section{Comparative Research in Law \& Political Economy}

\section{Michael Fakhri}

Anxieties and Aspirations: A Schematic Note on the Toronto Group for the Study of International, Transnational and Comparative Law

EDTORS: Peer Zumbansen (Osgoode Hall Law School, Toronto, Director, Comparative Research in Law and Political Economy, York University), J ohn W. Cioffi (University of California at Riverside), Lindsay Krauss (Osgoode Hall Law School, Toronto, Production Editor)

This paper can be downloaded without charge from the Social Science Research Network Electronic Library at: http:/ / ssrn. com/ abstractid=1128129 

CLPE Research Paper 11/2008

Vol. 04 No. 03 (2008)

\title{
Michael Fakhri
}

\section{AnXieties AND Aspirations: A Schematic Note ON THE TORONTO GROUP FOR THE STUDY OF INTERNATIONAL, TRANSNATIONAL AND COMPARATIVE LAW}

\begin{abstract}
This note concerns a conference of graduate students - in law as well as a number of other disciplines - which took place at the University of Toronto Faculty of Law on 11-13 January 2008. As the first of its kind convened by the newly established Toronto Group for the Study of International, Transnational, and Comparative Law, the conference was held with the aim of furthering ties between students with an interest in these fields of scholarship. By examining some of the ideational and geographical context of the Toronto Group, this article note brings to bear a better understanding of questions on polycentricity, fragmentation, and pluralism in international, transnational, and comparative legal scholarship. The city of Toronto is at a particular moment of cultural confidence that offers a vantage point for explicating the tensions, paradoxes, and dark sides of fragmenting international law and its centres of power. The increasingly developed graduate studies in law can take hold of this moment and actually create these emerging vantage spaces against law’s ideological functions.
\end{abstract}

Keywords: Global Law School, Global Cities, Graduate Studies, Legal Pedagogy, Legal Pluralism

JEL classification: K10, K33

Author Contact:

Michael Fakhri

Ph.D. Candidate, University of Toronto - Faculty of Law

78 \& 84 Queen’s Park, Toronto, Ontario, Canada

Research Fellow, Collaborative Urban Research Laboratory, Osgoode Hall Law School

Email: michael.fakhri@utoronto.ca 


\title{
ANXIETIES AND ASPIRATIONS: A SCHEMATIC NOTE ON THE TORONTO GROUP FOR THE STUDY OF INTERNATIONAL, TRANSNATIONAL AND COMPARATIVE LAW
}

\begin{abstract}
Michael Fakhri
"But I had the strong conviction that I could do it - born... of the necessary combination of confidence and ignorance that only a graduate student could have possessed".

- Robert Heilbroner ${ }^{1}$

"We know that the more a place is set apart for free play, the more it influences people's behavior and the greater is its force of attraction”.

- Ivan Chtcheglov²

\section{I.}

This note concerns a conference of graduate students - in law as well as a number of other disciplines - which took place at the University of Toronto Faculty of Law on 11-13 January 2008. As the first of its kind convened by the newly established Toronto Group for the Study of International, Transnational, and Comparative Law, the conference was
\end{abstract}

\footnotetext{
* S.J.D. Candidate (Toronto); LL.M. (Harvard); LL.B. (Queen's); B.Sc. (University of Western Ontario). I would like to thank Umut Özsu for his comments on an earlier draft and for the conversations we have had on this topic. Certain ideas also came out of discussions at the Critical Research Laboratory in Law \& Society, Osgoode Hall Law School, York University, www.criticalresearchlab.org

${ }^{1}$ The Worldly Philosophers: The Lives, Times and Ideas of the Great Economic Thinkers (New York: Touchstone, 1995) at 8 [emphasis in original].

2 “Formulary for a New Urbanism” in Ken Knabb, ed. and trans., Situationist International Anthology (Berkeley: Bureau of Public Secrets, 1989) 1 at 4 [emphasis in original].
} 
held with the aim of furthering ties between students with an interest in these fields of scholarship. ${ }^{3}$ Determining the "achievements" of any such conference, particularly one as heterogeneous and multi-faceted as this, is never a straightforward task. Nor ought it to be, for if it aims to "accomplish" anything at all, the Toronto Group seeks to create a space within which we and others may develop a more nuanced understanding of themselves and their research within the context of something resembling a community.

By examining some of the ideational and geographical context of the Toronto Group, this article note brings to bear a better understanding the theme of this edition of the Journal of International Law and International Relations engaging with questions of polycentricity, fragmentation, and pluralism in international, transnational, and comparative legal scholarship.

\section{II.}

The first step is to identify clearly what needs to be overcome on a global level - we are still recovering from the globalization hang-over of the 1990s, during which the constant message was that, whether we liked it or not, the world had come to be interconnected via novel communication and transportation technologies in unprecedented ways. Many of us initially felt overwhelmed and disempowered by this image of abstract interconnection, which seemed to have been brought upon us like a force of nature. We were told that international institutions are necessary, economic integration inevitable, and the market paramount. The chief question, however, is not whether we are interconnected, but how we are interconnected and how we want to co-exist socially, economically, politically, and ecologically. Moreover, historical inquiries into the mechanisms with which institutions have connected us in the past help us to understand why we are in the sort of world we live in today. How do ideas diffuse through legal practice and institutions? Who are the actors generating norms that have a global effect? What systems of political

\footnotetext{
${ }^{3}$ For details, see: http://www.law.utoronto.ca/visitors_content.asp?itemPath=5/7/0/0/0\&contentId=1591.
} 
economy are being constructed and conjoined? Which legal institutions are being transformed and by whom and what?

These questions also allow us to move past simple phrases such as "post-nationalism” or "post-Westphalian”. Everyday and theoretical accounts of states and international institutions have always been flexible, though not infinitely so, and we should therefore aim to construct a world informed with the experience of the transient nature of such entities. We have lived this transience. We are all born into a nation-state different in character or geography than that of our parents. Increasing numbers of individuals find themselves in the position of being immigrants, expatriates, or refugees, and have accepted the responsibility of contributing to the construction of states different from those in which their childhoods were spent. Moreover, many of us have found that the nation-state of one's childhood has disintegrated or been enlarged during the course of our lives. By the time international legal scholarship came to recognize that the classical, "Westphalian" nation-state was no longer the paramount unit of international law and began to express its anxieties with respect to the proliferation of international institutions, many had already started to feel a certain ennui with traditional accounts of nationalism, statehood, and the international sphere. This sense of tedium does not necessarily require that emerging forms of scholarship need ignore states and institutions. What it does mean, however, is that we, as scholars, ought to view ourselves as free to examine international, comparative and transnational law and their sources with a less preconceived sense of whether we need to dispense with, co-opt, or perhaps even support the subjects of our analyses. In other words, such ennui, coupled with the realization that traditional conceptions of the state and international institutions no longer command broad-based support, force us and other legal scholars to explain, clearly and sincerely, why it is that we fashion or subscribe to particular research agendas. Despite - or, perhaps, precisely because of - this ambivalence with respect to our subjects of analysis (whether these be institutions, doctrines, or fields of study), we have little reason not to be aware of the moral responsibility inherent in our descriptions, critiques, and choices of subject. Such descriptions, critiques, and choices always legitimize and delegitimize certain ideas, and always empower and silence certain voices.

There remains, however, a dearth of analytical tools and discursive frameworks to express this ennui. International, transnational, and comparative legal scholarship has, in the last two decades, generally been 
thinned out by flippant idealism, fatalistic apology, tepid pragmatism, or naïve hopefulness. Nevertheless, new work is emerging that, like previous critical scholarship, unpacks dogma and provides the analytical tools to facilitate the task of making the difficult choices of constructing alternatives through negotiating conflicting political interests.

In order to understand the sensitivities and predispositions of the Toronto Group, it is necessary to understand our particular circumstances as graduate students resident within the city of Toronto. The city shapes our questions and provides us with the physical, intellectual, and cultural space to explore these questions further and on a global scale. Toronto exemplifies the fragmentation and pluralism discussed below and the interconnectedness mentioned above.

Toronto is being built by those accustomed to being out of place. "Toronto is the most multi-cultural city in the world!" is the unofficial slogan of this sentiment, capturing the multitude of ethnic groups that continuously stream into the city. Alongside this frequently referenced sentiment is the fact that half of its inhabitants were born outside of Canada. ${ }^{4}$ What is important is not whether or not this Toronto is the "most" diverse city in the world, but the context of this particular form of diversity.

This is a relatively young city compared to other cities of its economic and demographic size. Until the 1970s, Toronto was known as "Toronto the Good" due to its conservative moral conviction, which was felt in its laws and public institutions. Starting in the 1970s and well into the 1980s, it became a centre of global finance, manifested in the construction of a concentrated financial district downtown. Professional (including legal) and technical services became Toronto's financial centrepiece in the 1990 s. $^{5}$

\footnotetext{
${ }^{4}$ See Francine Kopun and Nicholas Keung, "A city of unmatched diversity” The Toronto Star (5 December 2007), online: http://www.thestar.com/News/GTA/article/282694. See also Jonathan Spicer, "Toronto takes on London, New York in diversity game” Reuters (27 December 2007), online: http://www.reuters.com/articlePrint?articleId=USN2151421720071227. Spicer outlines problems associated with the claim that one is "the most diverse".

${ }^{5}$ Saskia Sassen, Cities in a World Economy, $3^{\text {rd }}$ ed. (London: SAGE Publications, 2006) at $122-125$.
} 
For at least a decade, Toronto has been emerging from a cultural insecurity that vexed its self-identity. ${ }^{6}$ Toronto often looked to nonCanadian cities for cultural cues, and it still tends to look beyond its own borders. What the world thinks of Toronto, what Toronto thinks of the world, how the world affects Toronto - such concerns are often felt by its inhabitants. Toronto, however, is in a unique moment in which it has begun to look inward before it looks outward. This self-confidence is evidenced by more than just the recent prevalence of large, public architectural projects with which the downtown area has come to be dotted; we feel it in the city's poems ${ }^{7}$, writings ${ }^{8}$, displays of art $^{9}$, and cultural and communicative networks. ${ }^{10}$

This is why we find studying international, comparative, and transnational law so rewarding in Toronto. Acutely aware of the rest of the world, this is a city in the midst of a defining moment.

"The hucksters and tourism shills tell us that Toronto is an intellectual city, a city of ideas.... The question for Toronto now is not whether ideas can flourish in this place, because demonstrably they do, but what consequences in justice that flourishing will

\footnotetext{
${ }^{6}$ Of course, this is not to say that Toronto's cultural landscape before this last decade was not worthwhile, see, e.g., Lynn Crosbie, “Alphabet City” in John Knechtel, ed., Open City (Toronto: Anansi Press, 1998) 44. Crosbie, a Toronto poet and critic, explores the city's cultural geography of the 1980s and 1990s.

7 See, e.g., Pier Giorgio Di Cicco, Municipal Mind: Manifestos for the Creative City (Toronto: Mansfield Press, 2007)

${ }^{8}$ See, e.g., Jason McBride and Alana Wilcox, eds., uTOpia: Towards a New Toronto (Toronto: Coach House Books, 2005); David McFarlane, Toronto: A City Becoming (Toronto: Key Porter Books, 2008); and spacing, a magazine that began in 2004 and is dedicated “to studying Toronto’s urban landscape”, online: http://spacing.ca.

${ }^{9}$ Here I am thinking of examples such as AlleyJaunt, which converted the city's alleys into open galleries, the recent experiment with the all-night art festival Nuit Blanche, and the relocation of the Museum of Contemporary Canadian Art to 952 Queen Street West in downtown Toronto.

10 See, e.g., the Collaborative Urban Research Laboratory, an interdisciplinary research facility at York University for interdisciplinary and multimedia research on social and material urban infrastructure, online: www.criticalresearchlab.org. See also the Arts \& Crafts record label, online: http://www.arts-crafts.ca.
} 
entail. On the edge of new identities and possibilities, what is our idea of justice?"11

Similarly, the question that arises in Toronto is not "does the 'international' truly exist” or "is international law relevant?", but rather 'what idea of international law do we want?" Confronted with these questions, Toronto cannot take for granted that it must always question what the "we" in this question actually amounts to. This is reflected in scholarship associated with Toronto, which regularly produces and engages with approaches to international law distinct from those commonly defined as "Western" and/or "liberal". This is also reflected in the large number of professors at the city's two law schools who incorporate international, comparative, and transnational law into their work or make it the subject of their research.

This cultural moment of self-confidence within an internationalist milieu reflected in Toronto's legal scholarship may manifest itself in two ways. The first, and naïvely confident, way would involve an attempt to universalize the particular experience of Toronto beyond its borders as seamlessly and convincingly as possible. This would likely entail a celebration of Toronto's success with managing diversity and a concomitant attempt to employ this as a model for export and comparison. This would take the diversity of the city as an institutionalized, fully crystallized fact rather than as a constantly negotiated dynamic, embracing "multiculturalism" without acknowledging the dominant European/Christian framework that constitutes much of the city's cultural background. ${ }^{12}$ Alternatively, we could highlight the particular experience of Toronto as a way of understanding how interaction between different groups and interests - again, understood in the broadest possible sense ought to take place on the global plane. The former suggests a buried sense of power and privilege. The latter emphasizes an examination of interconnectedness.

The other particularity that we experience and that influences the Toronto Group's scholarship relates to the fact that we are graduate

\footnotetext{
${ }^{11}$ Mark Kingwell, “Toronto: Justice Denied” The Walrus 5:1 (January/February 2008) 58 at 59 .

12 Mariana Valverde, “Toronto: A 'Multicultural' Urban Order" in Andreas Philippopoulos-Mihalopoulos, ed., Law and the City (London: Routledge, 2007) 191.
} 
students of law in Canada. The notion of rigorous graduate legal studies at the doctoral level as a de facto prerequisite to the Canadian legal academy is a recent phenomenon. In the past, the majority of law professors had an LL.M. (often from the US or UK) at most. In the last ten years, however, a doctorate in law has become increasingly common; and in the last five years, a doctorate in law has established itself as the norm. This has coincided with significant increases in the number of doctoral programs in law, the number of students completing their doctorates in law in Canada, and government funding for doctoral programs in law. ${ }^{13}$ Doctoral programs of these sizes are new, and students and faculty are both having to define what it means to do doctoral studies in law as they go along which is an exhausting luxury. Moreover, as graduate students question their role as international jurists in the world, both of Toronto's law schools look to securing their status as "Global Law Schools" in the coming years. ${ }^{14}$

The educational path of the legal scholar in Canada will, then, often be as follows: undergraduate degree in any discipline; first law degree; year of articles, which may include clerking for a judge; master of laws; and a doctorate of law. Of course, many have work experience sprinkled throughout as well as non-law graduate degrees. The master of laws usually involves coursework and a mandatory research paper which is regarded as a significant part of the degree. The doctorate will only have one or two required courses, which usually concern research methodology.

13 Notes from the "Dean's Panel” at the Osgoode Hall Law School's Graduate Law Students Association Annual Conference 2007 (4 May 2007) (on file with authors). Members of the panel included Dean Patrick J. Monahan (Osgoode Hall Law School), Associate Dean J. Anthony VanDuzer (University of Ottawa Faculty of Law), Associate Dean Arthur Cockfield (Queen's University Faculty of Law), Dean Hannah R. Arterian (Syracuse University College of Law).

${ }^{14}$ Recently, two prominent deans of US law schools provided an external review of the University of Toronto Faculty of Law. They drew upon their US experiences as reference points and advanced the claim that the school has the potential of being one of the few non-US “Global Law Schools” that are likely to emerge in the coming decades. See online: http://www.law.utoronto.ca/documents/general/ExternalReview2006.pdf. Osgoode Hall Law School has similar aims of being a “Global Law School”. See "Plan for the Law School 2006 - 2010”, online:

http://www.osgoode.yorku.ca/about/documents/plan_for_the_law_school_20062010.pdf. 
This recent trend has created a particular set of anxieties and aspirations for graduate students. We now have a set of questions in which the past provides little guidance as to how to answer questions such as: what is the doctorate of law and what does it achieve? what is the purpose of a legal scholar? is graduate legal education a fundamentally philosophical, humanities-based, or social scientific matter? what do I, as a legal scholar, have to say that is different than those in other disciplines? what is the purpose of legal theory? These anxieties are magnified in international law, which has usually been relegated to the margins in the Anglo-American legal tradition, episodically being dogged by the question as to whether it is even law "properly so-called".

We cannot ignore Toronto's relationship to the US and the effect that this has had on legal academia. Toronto is the third largest financial centre and boasts the third largest concentration of private information communication technology facilities in North America. ${ }^{15}$ The US and Canada are each other's largest trading partners (US trade contributing a significantly larger percentage of income to the Canadian economy than Canadian trade does to the US). All this occurs within the context of the North American Free Trade Agreement linking elements of the political economy of Canada and the US. The Canadian legal academy has, of course, been influenced by the political economy and legal academy of the US from the very inception of Canadian legal education. ${ }^{16}$ Arthurs identifies four narrative strands in this complex relationship, noting that (1) touring a set of elite American law schools has been the virtual prerequisite for newly-appointed deans; (2) Canadian law has, for at least 150 years, borrowed extensively from US law; (3) the Canadian legal profession has been influenced profoundly by developments in US legal practice; and (4) there has been a pervasive fear among Canada's business,

\footnotetext{
${ }^{15}$ See online: http://www.toronto.ca/toronto_facts/business_econdev.htm.

${ }^{16}$ Harry Arthurs, "Poor Canadian Legal Education: So Near to Wall Street, So Far From God” (2000) 38 Osgoode Hall L. J. 381. Arthurs has examined this complex relationship in several articles: "The World Turned Upside Down: Are Changes in Political Economy and Legal Practice Transforming Legal Education and Scholarship, or Vice Versa?" (2001) 8 Int'l J. of the Legal Profession 11; “The State we're In: Legal Education in Canada's New Political Economy” (2001) 20 Windsor Y.B. Access Just. 35; “The Political Economy of Canadian Legal Education” (1998) 25 J. L. Soc’y 14; "Globalization of the Mind: Canadian Elites and the Restructuring of Legal Fields" (1997) 12 Can. J. L. \& Soc. 219
} 
media, professional, and academic elites that Canadian talent will be lost to the US. ${ }^{17}$

This trend continues today. Especially relevant for our purposes is that Toronto's first “international” reference-point is the United States, which has the effect of filtering all things "international" through the prism of US debates and disputes. Negotiation with the US is part of Toronto's daily life. The University of Toronto was the first Canadian law school to re-designate its general law degree from the historically British LL.B. (Bachelor of Laws) to the American-style J.D. (Juris Doctor). ${ }^{18}$ The University of Toronto website explains that this change was undertaken as part of a move to reflect the fact that most students enter law school with at least one undergraduate degree. "This is particularly important for the increasing numbers of $\mathrm{U}$ of $\mathrm{T}$ students and graduates who choose to work or study outside Canada." 19 At least 15\% of the Class of 2008 is expected to spend their first year after law school in the United States, with numbers expected to rise over the following years. ${ }^{20}$

Despite this relationship with the US, being a graduate student of law in Canada is a unique experience. This came to the fore while we were organizing this conference. We had trouble determining how to send the call to US law schools where the J.D. is considered satisfactory for gaining entry into the legal academy. If we were to target US J.D.s, did we also have to target Canadian LL.B./J.D.s? The two programs, their profiles and compositions, clearly share a significant number of similarities. Would it be best to send the call only to LL.M. and doctoral students when dealing with US schools? The problem with that approach was that it was unlikely to get US nationals, since these programs are composed largely of non-US students. In the end, we decided to leave it open and allow self-selection to determine participation at the conference.

The receptivity to themes of polycentricity, fragmentation, and pluralism in Toronto is by no means accidental. Indeed the ambiguities

\footnotetext{
${ }^{17}$ Arthurs, “The World Turned Upside Down”, ibid. at 12.

18 Joseph Berkovits, “U. of T. to get J.D. Degree: opinions divided over whether new degree is forward thinking or a sign of Americanization” Ultra Vires (October 2000).

19 See:

http://www.law.utoronto.ca/prosp_stdn_content.asp?itemPath=3/6/15/6/0\&contentId=983

- J.D.

${ }^{20}$ Robert Wakulat, “Articling results are in” Ultra Vires (16 October 2007)
} 
and tensions of the city correspond to the like in legal literature. The proliferation of regimes wielding varying levels of self-sufficiency in relation to matters arising within such fields as trade, environmental, and human rights law has been a source of both grief and enthusiasm.

Koskenniemi and Leino have argued that extreme discomfort and concern, which this development has generated within circles of “classical international law", stems from the prospect of an already fragile and unconfident international legal order splintering beneath the weight of "proliferating tribunals, overlapping jurisdictions and 'fragmenting' normative orders." 21 This fragmentation, they argue, is unintelligible in the absence of an appreciation for the hegemonic struggle being waged between rival juridico-political bodies seeking to translate its own professional language "into a global Esperanto, to have its special interests appear as the natural interests of everybody." 22 Teubner and FischerLescano argue that global legal pluralism is not the result of conflicting political or legal norms, but "rather has its origin in contradictions between society-wide institutionalized rationalities, which law cannot solve, but which demand a new legal approach to colliding norms."23 "Accelerated differentiation of society into autonomous social systems" is what has generated this fragmentation (and not the global economy) and it is the "expansionist" fervor of these systems that cause global problems. ${ }^{24}$ Both these perspectives do not seek some unifying element yet distinctions between Koskenniemi and Teubner arise from their differing perspectives regarding the definition of "political" and the role the individual has to play in generating law. ${ }^{25}$ Still others have presented fragmentation as a

21 Martti Koskenniemi and Päivi Leino, "Fragmentation of International Law? Postmodern Anxieties” (2002) 15 Leiden J. Int’l L. 553 at 561.

${ }^{22}$ Ibid at 578.

${ }^{23}$ Andreas Fischer-Lescano and Gunther Teubner, "Regime-Collisions: The Vain Search for Legal Unity in the Fragmentation of Global Law” (2003-2004) 25 Mich. J. of Int'l L. 999 at 1004

${ }^{24}$ Ibid. at 1006-1007.

${ }^{25}$ Contrast Martii Koskenniemi, The Gentle Civilizer of Nations: The Rise of Fall of International Law 1870 - 1960 (Cambridge: Cambridge University Press, 2001) with Gunther Teubner, "How the Law Thinks: Toward a Constructivist Epistemology of Law" (1989) 23 Law \& Society Review 727. 
fundamentally "healthy phenomenon", ${ }^{26}$ arguing that it accords with the basic parameters of the international order and cannot therefore be regarded as a genuine threat, ${ }^{27}$ put forth proposals for a model of international legal order in which unity and fragmentation would "go hand in hand", ${ }^{28}$ refrained from passing judgment on the phenomenon so as to offer a general taxonomy of the various forms of fragmentation thrown up by international law's expansion. ${ }^{29}$

This debate has coincided with the renewed attention to the claim, long popular among socio-legal researchers, that "law" is not restricted to formal rules derived from the state or official institutions. Recently, legal pluralist literature has taken a turn towards the international/global. In the past, legal pluralist literature debated whether legal pluralism scholarship should examine law was as a socio-legal phenomenon or whether to adopt pluralism as a methodology. Now the tension emerges in terms of treating "globalization" as either an irrefutable phenomenon generating law or as a series of processes that are formed by and generate law. For example, Berman is not concerned with how empirically interconnected the world is, rather he argues that what mattes is that people are acting as if globalization were a real phenomenon. Globalization, he suggests, particularly with regard to trade liberalization and open markets, is a new form of hegemony leaving little possibility for a rival ideology to survive. ${ }^{30}$ Similarly, Tamanaha argues that globalization, which he defines as the fact that "the world is being linked together in a variety of different ways”, is a dominant a factor chipping away at traditional concepts of

${ }^{26}$ Georges Abi-Saab, “Fragmentation or Unification: Some Concluding Remarks” (19981999) 31 N.Y.U. J. Int’l L. \& Pol. 919 at 925.

27 Mario Prost and Paul Kingsley Clark, “Unity, Diversity and the Fragmentation of International Law: How Much Does the Multiplication of International Organizations Really Matter?” (2006) 5 Chinese J. Int'l L. 341 at 348 and 368.

28 Joost Pauwelyn, "Bridging Fragmentation and Unity: International Law as a Universe of Inter-Connected Islands” (2003-2004) 25 Mich. J. of Int’l L. 903 at 904.

29 Matthew Craven, "Unity, Diversity and the Fragmentation of International Law" (2003) 14 Finnish Yearbook of International Law (Leiden/Boston: Martinus Nijhoff Publishers, 2005) 3 at 6 and 15.

30 Paul Schiff Berman, “From International Law to Law and Globalization”, (2005) 43 Columbia J. of Transnat'l L. 485 at 552-553. 
sovereignty and autonomy with regards to the nation state. ${ }^{31}$ Tamanaha is unsatisfied with the under-theorized and covertly essentialist accounts of law, which he sees as underlying a great deal of legal pluralist literature, arguing that "law is a thoroughly cultural construct" and that it cannot therefore "be captured in any single concept, or by any single definition"32; he leaves "globalization" as a given phenomenon separate from law. ${ }^{33}$

Others are unsatisfied to take pluralism and globalization for granted and look to how law and legal research contributes to generating both pluralism and interconnectedness. For example, Boaventura de Sousa Santos considers the "discrepancy between social experience and social expectation" and the tension between regulation and emancipation as the defining feature of modernity. ${ }^{34}$ Santos and others examine how law is formed through continuing struggles of social practice from all sorts of communities and social actors from subaltern spaces and not necessarily from preexisting normative hierarchies. ${ }^{35}$ Twining's research agenda uses a multiplicity of methodologies in order to address the question of global patterns of legal concepts emphasizing that the methodology will depend on the scholar's purpose. ${ }^{36}$ Twining considers "generalizations across legal families, traditions and cultures as problematic" and his agenda is to take stock as to how equipped we are "to make meaningful generalizations and

31 Brian Tamanaha, General Jurisprudence of Law and Society (Oxford: Oxford University Press, 2001) at 121-123.

${ }^{32}$ Brian Tamanaha, “A Non-Essentialist Concept of Legal Pluralism” (2000) 27 J. L. Soc'y 296 at 313.

33 Supra note 31 at $129-139$.

34 Boaventura de Sousa Santos, Toward a New Legal Common Sense: Law, Globalization, and Emancipation 2d ed. (London: Butterworths, 2002) at 2. See also Jeremy Weber, "Legal Pluralism and Human Agency” (2006) 44 Osgoode Hall L. J. 167 (2006).

35 Boaventura de Sousa Santos and César A. Rodríguez-Garavito eds., Law and Globalization From Below: Towards a Cosmopolitan Legality (New York: Cambridge University Press, 2005)

36 William Twining, "Have Concepts: Will Travel: Analytical Jurisprudence in a Global Perspective” (2005) 1 Int'l J. of L. in Context 5 at 12. 
comparisons about legal issues and phenomena”.37 Twining considers law and lawyers to be bound to their specific cultural background, but argues that legal orders are not isolated from other legal orders, cultures and systems. As such, he explores how a concept or group of concepts or models or frames travel and "diffuse". ${ }^{38}$ This is similar to recent work by comparative legal scholars who seeks to uncover the universalized extension of a particular legal tradition or consciousness that is universalized through the processes of global interconnectedness. ${ }^{39}$ Kleinhans and Macdonald's critical legal pluralist project is an effort to cast aside the essentialism characteristic of traditional forms of legal pluralism in favor of an account of identity formation sophisticated enough to illuminate subjectivity's role in the formation and reformation of law. By providing legal subjects with "access to and responsibility toward law", Kleinhans and Macdonald contend, critical legal pluralism "presumes that subjects control law as much as law controls subjects within its normative sphere". 40 "Polycentricity" is a term used by some to describe an approach that seeks to investigate co-existing, sometimes competing values, underlying law. This approach does not regard law as an external object to be studied, rather it considers law as a practice produced from within actors inside a particular context. ${ }^{41}$

${ }^{37}$ Id. at 6.

38 William Twining, "Diffusion of Law: A Global Perspective" (2004) 1 J. Legal Pluralism \& Unofficial L. 1 at 4-5. Twining prefers the term "diffusion" rather than "transplant" to overcome certain implicit assumptions and omissions in the concept of "transplant”

${ }^{39}$ See for e.g. H. Patrick Glenn, Legal Traditions of the World: Sustainable Diversity in Law (Oxford: Oxford University Press, 2000) at 50; and Duncan Kennedy, "Three Globalizations of Law and Legal Thought: 1850-2000", in David Trubek and Alvaro Santos eds., The New Law and Economic Development: A Critical Appraisal (Cambridge: Cambridge University Press, 2006) 95

${ }^{40}$ Martha-Marie Kleinhans and Roderick Macdonald, "What is Critical Legal Pluralism?” (1997) 12 Can. J. L. \& Soc. 25 at 38-39 and 40. For an application of this approach in international trade law see Robert Wolfe, "See You In Geneva? Legal (Mis)Representations Of The Trading System" (2005) 11 Eur. J. Int’l Relations 339.

${ }^{41}$ Ari Hirvonen, ed., Polycentricity: The Multiple Scenes of Law (London: Pluto Press, 1998); and Hanne Petersen and Henrik Zahle, eds., Legal Polycentricty: Consequences of Pluralism in Law (Aldershot: Dartmouth, 1995). 
Our fascination with fragmentation and pluralism need not commit us to a facile celebration of multiculturalism and plurality for its own sake. Indeed, Toronto in this moment can provide a space for scholarship that situates itself in the blurred area between revealing paradoxical tensions and unraveling powerful dogma. Toronto is sufficiently confident in its cultural power and proximate to the political economy of the US to offer a vantage point for explicating the tensions, paradoxes, and dark sides of international law and its centres of power. This same power and proximity also offers a potential space for counter-hegemonic action. The increasingly developed graduate studies in law can take hold of this moment and actually create these emerging vantage spaces against law's ideological functions, which Robert Cover described as "much more significant in justifying an order to those who principally benefit from it and who must defend it than it is in hiding the nature of the order from those who are its victims." ${ }^{, 2}$ At this point, then, you are invited to explore what is at stake and what is to be done with the diverse puzzles of polycentricity, fragmentation, and pluralism.

${ }^{42}$ Robert Cover, “Violence and the Word” (1986) 95 Yale L. J. 1601 at 1608. 